Case Report

\title{
Selective Termination for Fetal Anomaly in Twin Pregnancy
}

\section{Terminasi Selektif pada Kehamilan Ganda dengan Anomali Janin}

\author{
Putri Mirani, Aria Wibawa \\ Maternal-Fetal Division \\ Department of Obstetrics and Gynecology \\ Faculty of Medicine University of Indonesia \\ Dr. Cipto Mangunkusumo Hospital \\ Jakarta
}

\begin{abstract}
Objective: To discussed the ethical aspects, the technique, optimal timing and the possible outcome of selective termination in anomalous twin pregnancy.

Case description: A 28-year old primigravida, 21 weeks twin gestation, with giant hygroma coli in one fetus. The normal fetus was compressed by the anomalous fetus with oligohydramnios. The parent decided to undergo selective termination of the abnormal fetus. The procedure perform was intracardiac injection of potassium chloride (KCl). Eight milliliters of $\mathrm{KCl}$ were injected into fetal cardiac, followed by bradicardia and asystole of the anomalous twin. A week after the procedure, the normal fetus also died and delivered spontaneously after induction.
\end{abstract}

Conclusion: Selective termination for fetal anomaly in twin pregnancy have some aspects to be considered.

[Indones J Obstet Gynecol 2013; 37-1: 57-60]

Keywords: selective feticide, selective termination

\begin{abstract}
Abstrak
Tujuan: Membahas aspek etik, tehnik, waktu yang paling optimal dan kemungkinan luaran janin pada terminasi selektif kehamilan ganda dengan anomali janin.

Kasus: Seorang ibu primigravida usia 28 tahun, kehamilan kembar dengan usia kehamilan 21 minggu, salah satu janin mengalami kelainan higroma coli. Janin yang normal terdapat oligohidramion dan terkompresi oleh janin yang mengalami anomali. Orang tua janin memutuskan untuk melakukan terminasi pada janin yang mengalami anomaly. Prosedur yang dilakukan adalah injeksi potassium klorida (KCl) intrakardiak. Delapan milliliter KCL diinjeksikan pada jantung janin yang mengalami anomali, diikuti bradikardia dan asistol. Satu minggu setelah prosedur, janin yang normal juga meninggal dunia dan kedua janin dilahirkan spontan setelah dilakukan induksi persalinan.
\end{abstract}

Kesimpulan: Terminasi selektif pada kehamilan ganda dengan anomali janin harus mempertimbangkan beberapa aspek.

[Maj Obstet Ginekol Indones 2013; 37-1: 57-60]

Kata kunci: fetisida selektif, terminasi selektif

Correspondence: Putri Mirani, Maternal-Fetal Division, Department of Obstetrics and Gynecology. Dr Cipto Mangunkusumo Hospital. Jakarta. Telephone: 08127103995 Email: miraniroseno@yahoo.com

\section{INTRODUCTION}

Congenital malformations in twin pregnancy occur more commonly as compared with singleton pregnancy and it is an important contributor to increased perinatal mortality associated with multiple pregnancy. The incidence of malformation thought to be more common in monozygotic than dizygotic twin pregnancies. ${ }^{1,2}$

The management will be influenced by the type of abnormality, whether or not it is discordant, gestational age when diagnosed and chorionicity. There are three management options available; expectant management, selective termination of the anomalous fetus and termination the entire pregnancy. ${ }^{1}$

In cases of higher-order multi-fetal gestation, reduction in the number of fetuses to two or three improves survival of the remaining fetuses. Selective reduction (multifetal pregnancy reduction) use in early pregnancy intervention to reduce the number of embryo ( $1^{\text {st }}$ trimester). Selective termination is performed later when fetal abnormality has been diagnosed (after $2^{\text {nd }}$ trimester). ${ }^{3}$

This case report will discuss selective termination in anomalous twin pregnancy and the aspects regarding the action.

\section{CASE ILLUSTRATION}

A 28 years old primigravida, gestational age of 21 weeks with monochorionic-diamniotic twin pregnancy. One fetus was diagnosed with giant hygroma coli and the other fetus was normal. The normal fetus was compressed by the abnormal fetus. After counseling the parents, it was decided to 
perform selective feticide with intracardiac $\mathrm{KCl}$ injection.

The first attempt of $\mathrm{KCl}$ injection was performed with the injection of $6 \mathrm{ml}$ of $\mathrm{KCl}$ to the abnormal fetal heart. Before that, aspiration of $300 \mathrm{ml}$ fluid on the hygroma coli was perform. Then, $\mathrm{KCl}$ injected gradually through the fetal cardiac until the bradycardia followed by asystole were observe. This first attempt was unsuccessful with reinitiation of fetal heart beat after the needle was removed. The procedure was repeated a week later.

On second attempt of the procedure, the step of action is similar with the first one with the difference in $\mathrm{KCl}$ dose $(8 \mathrm{ml})$ and we did not remove the needle after the anomalous fetal death was confirmed.

Unfortunately, in follow up a week after the procedure, the normal fetus also die. Both fetus was delivered spontaneously after labor induction.

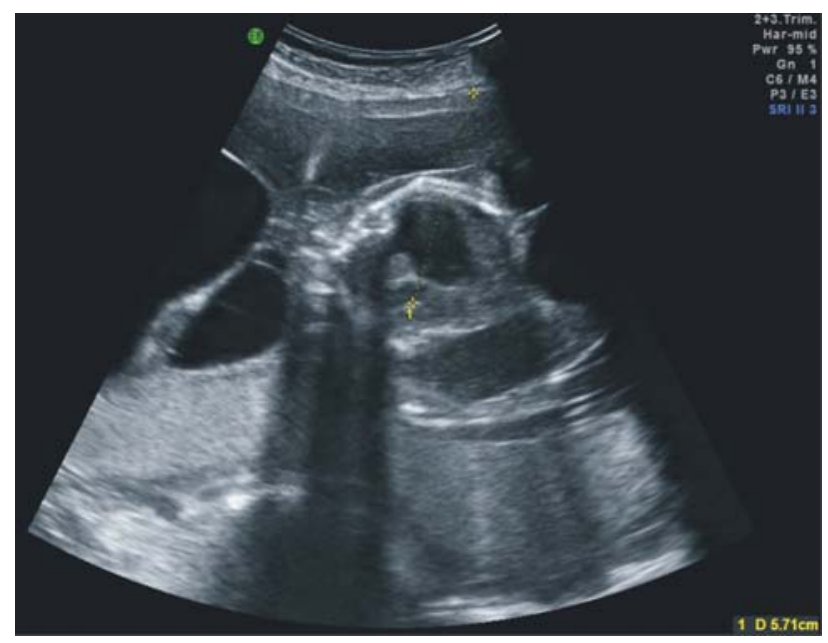

Figure 1. Fetus with cystic hygrome

\section{DISCUSSION}

When multiple gestation complicated by the discovery of a significant anomaly in one fetus, counseling of the parents and management decisions are difficult. Factors to incorporate into the decision-making analysis include: Severity of the anomaly, chorionicity of the pregnancy, effect of the anomalous fetus on the normal co-twin or co-triplets and ethical beliefs of the parents. ${ }^{4}$

In this case, the consideration for selective termination were; parent's decision after counseling about the risk and prognosis of the pregnancy, there was severe fetal anomaly and will affect the healthy co-twin.

There are specific ethical differences between selective termination and multifetal pregnancy reduction and that of abortion. A woman has an abortion usually does not wish to have the child. In contrast, a woman undergoes selective termination or multifetal reduction is wish to have a healthy child. ${ }^{6}$

There are some ethical issues in selective fetal termination. There are three ethical concepts and framework; respecting the autonomy of the pregnant woman, respecting the fetus as a patient and respecting the individual conscience of the physician. ${ }^{7}$

Respecting the autonomy of pregnant women requires the physician to provide patients with clinical information that they need and then acknowledge and carry out the value-based preferences of the adult, competent patient unless there is compelling ethical justification for not doing so. ${ }^{7}$

Because of the immaturity of the fetal CNS, the fetus lacks the capacity to generate a perspective on its interests, the ethical principle of respect for autonomy and the concept of autonomy-based rights therefore do not apply to the fetus. ${ }^{7}$

When fetus presented to the physician and there is of sufficient maturity that, given the availability of biotechnological support and it can survive into the neonatal period and later achieve moral status so fetus is a patient. The pre-viable fetus has no claim to the status of being a patient independently of the pregnant woman's autonomy. ${ }^{7}$

Physicians have individual consciences which are the sources of morality other than professional medical ethics (i.e., personal experience, family upbringing, and religion).

Respecting the individual conscience of each individual physician means that some pregnant women can not become or continue to be patients of a particular physician. ${ }^{7}$

There are 4 categories for which recommendations of induced abortion or feticide are considered. First, maternal condition or treatment of such a condition will increased risk to the pregnant woman's health or life should she continue her pregnancy. Second, continuing pregnancy without feticide will increases the risk to the health or life of fetus(es). The third is when severe anomaly has been diagnosed. The last, complications that threa- 
ten the woman's health or life and salvage of the fetus is clinically hopeless. ${ }^{2,7}$

This case ethical consideration based on the autonomy of the pregnant woman and the individual conscience of the physician. Respecting the fetus as a patient is not applicable (non-viable fetus, severe anomaly, continuing pregnancy without feticide increases the risk to the health or life of fetus(es).

There are several techniques available for selective termination, depend on the chorionicity of pregnancy. Hysterotomy is the last resort procedure. The major issue is terminating the correct fetus. Extreme caution in monozygotic or monoamniotic twins because they shared single placenta without differentiation between two fetuses. ${ }^{8}$

There are several techniques can be apply in dichorionic twin gestation such as potassium chloride $(\mathrm{KCl})$ injection intracardiac or intrafunic, air embolization, exsanguination, cardiac tamponade and hysterotomy. ${ }^{8}$

For monochorionic twin gestation, selective termination can be done with absolute alcohol injection, alcohol-soaked suture fragments, metal coil, occlusive substances, suture ligation, monopolar cauterization, bipolar cauterization and radiofrequency ablation technique. ${ }^{8-10}$

Intracardiac $\mathrm{KCl}$ injection is not an option in monochorionic twin pregnancy. Bipolar cauterization is a safe and reliable technique to the selective isolation of the fetal circulations. It is a minimally invasive alternative to suture cord ligation or cord embolization procedures, particularly at later gestations. $^{8}$

There are some different opinions regarding the optimal timing to perform selective termination procedure. Some authors suggested to perform selective termination in $20^{\text {th }}$ weeks gestation because at that time it is possible to diagnose fetal malformation. Shalev J et al., 1999, suggested to perform the procedure around 28 to 32 weeks gestation to reduce the loss rate of the fetuses. In twin to twin transfusion syndrome (TTTS), laser coagulation is best to perform as early as 16 weeks (before 21 weeks) gestation.

In this case report, we performed intracardiac $\mathrm{KCl}$ injection in 21 weeks gestation. We choose to underwent these procedure because we do not have any other methods or equipment that we can apply to the anomalous fetus in our institution. The parents were already counseled regarding the risk of failure of this procedure and the possibility of losing both fetuses.

Our consideration is because the anomalous fetus was hydrops and compressed the healthy cotwin. It is worth to try because, even in other techniques for selective termination for monochorionic twin such as injection of sclerotic agents (alcohol) or occlusive substance (metal coil), there still the risk for leaking of the substance to the circulation of normal fetus. ${ }^{8-10}$

There were some possible causes of death of the normal fetus. First, in monochorionic twin the fetus sometimes shared the same artery or venous circulation, so that there is a possibility of $\mathrm{KCl}$ leaking into normal fetus circulation. The other possibility is, the death of the abnormal fetus can cause the hemodynamic instability such as sudden and permanent drop of blood pressure in normal fetus that may cause the organ damage followed by death of the normal fetus. ${ }^{8-11}$

\section{CONCLUSION}

Selective termination of anomalous fetus in twin pregnancy can be an option to reduce the morbidity and mortality of normal co-twin. To perform the procedure, there are some aspects to be considered such as the ethical aspect, the technique that applicable and the optimal timing to perform the procedure.

In this case report, the technique that performed was not the best option for the pregnancy, but the steps and timing when performing the procedure was appropriate.

However, the outcome of procedure was not satisfying because of the death of both fetuses.

\section{REFERENCES}

1. Bianchi DW, Chrombleholme TM, D'Alton ME, Malone FD. Malformation in Twins. In: Fetology Diagnosis and Management of the Fetal Patient $2^{\text {nd }}$ ed. New York: McGraw-Hill USA; 2010: 803-10

2. Mastroiacovo P, Castilla EE, Arpino C. Congenital malformation in twins: an international study. Am J Med Genet 1999; 83: $117-24$ 
3. Cunningham FG, Leveno KJ. Obstetrical Complications. In: William's Textbook of Obstetric $23^{\text {rd }}$ ed. New York: McGrawHill USA; 2010: 884-5

4. Deprest JA, Gratacos E, Lewi L. Invasive Fetal Therapy. In: Creasy and Resnik's Maternal Fetal Medicine: Principles and Practice $6^{\text {th }}$ ed. Philadelphia: Saunders USA; 2009: 434-70

5. Evans MI, Rodeck CH, Johnson MP, Berkowitz RL. Selective Termination. In: Prenatal Diagnosis. New York: McGraw-Hill USA; 2006: 571-8

6. Jenkins TM, Wapner RJ. The challenge of prenatal diagnosis in twin pregnancies. Curr Opin Obstet Gynecol 2000; 12: 87-92

7. Chervenak FA, McCullough LB. An ethically justified practical approach to offering, recommending, performing, and referring for induced abortion and feticide. Am J Obstet Gynecol 2009; 201: 560.e1-6
8. Rustico MA, Baietti MG, Coviello E, Orlandi, Nicolini U. Managing twins discordant for fetal anomaly. Prenat Diagn 2005; 25: 766-71

9. Eddleman KA, Stone JI, Lynch L, Berkowitz RL. Selective termination of anomalous fetuses in multifetal pregnancies: two hundred cases at a single centre. Am J Obstet Gynecol 2002; 187: 1168-72

10. Evans MI, Goldberg JD, Dommergues M. Efficacy of second trimester selective termination for fetal abnormalities: international collaborative experience. Am J Obstet Gynecol 1999; 181: 893-7

11. Malone FD, Craigo SD, Chelmow D, D'Alton E. Outcome of twin gestation complicated by a single anomalous fetus. Obstet Gynecol, 1996; 88: 1-5 